\title{
Symulacja pola naprężeń w spoinach z wykorzystaniem MES
}

\section{Simulation of the stress field in the welded joint using FEM}

\section{Streszczenie}

W codziennej praktyce projektowej obliczenia spoin pachwinowych są wykonywane w oparciu o metodę zawartą w obowiązkowej do stosowania normie PN-EN 1993-1-8:2006. Wynikiem obliczeń jest naprężenie zredukowane wyznaczane analitycznie dla przekroju krytycznego. Norma nie odnosi się do zjawiska koncentracji naprężeń, która ma miejsce w złączu w wypadku stosowania spoiny pachwinowej. W poniższej pracy zastosowano metodę elementów skończonych w celu oszacowania tego zjawiska.

Słowa kluczowe: symulacja MES; spoina pachwinowa; spoina czołowa; koncentracja naprężenia w spoinach

\begin{abstract}
The calculation of the fillet welds are performed based on the method delivered by the standard PN-EN 1993-1-8:2006. The typical result of the calculations is the Huber-Mises criteria for the critical section. The standard does not refer to the phenomenon of stress concentration that have to take place in the welded joint in case of incomplete fusion. In this paper the finite element method is used to estimate precisely this phenomenon.
\end{abstract}

Keywords: FEM Simulation; fillet weld; butt weld; stress concentration in the welds

\section{Wstęp}

Określenie rozkładu naprężenia w spoinie pachwinowej jest $w$ literaturze przedmiotu opisywane $z$ reguły w sposób szkicowy [1,2]. Było to zrozumiałe, z uwagi na brak narzędzi mogących precyzyjnie opisać to zagadnienie. Jednakże przez ostatnie dwie dekady obserwuje się bardzo szybki wzrost jakości oprogramowania wspierającego proces projektowy. Stosowanie metod komputerowych pozwoliło na radykalne skrócenie etapu projektowania inwestycji oraz na zwiększenie dokładności obliczeń wytrzymałościowych. Ponieważ wiodące programy opierają się na metodzie prętowej oraz na zależnościach zawartych w normach, to żaden z nich nie jest przystosowany do opisu różnych zjawisk nieopisanych w normach. Jednym z nich jest występujące w złączach spawanych zjawisko koncentracji naprężeń. Narzędziem, które jest przystosowane do rozwiązywania tego typu zagadnień jest metoda elementów skończonych (MES). W tej pracy, na bardzo prostym układzie statycznym, wykonane zostało porównanie naprężeń w spoinie pachwinowej i czołowej, obliczone metodą analityczną oraz programem Ansys.

Obecnie upraszcza się proces projektowy. Codzienna praktyka pokazuje, że tylko dla odpowiedzialnych konstrukcji i w ich najważniejszych węzłach spoiny są liczone metodą podaną w PN-EN 1993-1-8:2006 [3]. Poniższa praca pokazuje jednak, że nawet dla najprostszego przypadku obliczeniowego w spoinie pachwinowej w pewnych warunkach dochodzi do lokalnego przekroczenia naprężeń.

\section{Schemat statyczny}

Do obliczeń zastosowano prosty schemat belki zginanej siłą skupioną w jej osi obojętnej zamocowanej do niesprężystej blachy za pomocą złącza spawanego. Dobrano kształtownik zamknięty, kwadratowy formowany na zimno wg PN-EN 10025-2 [4] o następujących parametrach:

- wymiary: $100 \times 100 \times 6,3 \mathrm{~mm}$,

- materiał: stal S 235,

- sprężysty wskaźnik wytrzymałości $\mathrm{W}_{\mathrm{x}}=67,1 \mathrm{~cm}^{3}$,

- granica plastyczności $\mathrm{f}_{\mathrm{yb}}=235 \mathrm{MPa}$,

- wytrzymałość na rozciąganie $\mathrm{f}_{\mathrm{u}}=360 \mathrm{MPa}$.

Warunkiem granicznym jest ugięcie belki na poziomie 1/150. Dla tego warunku siła skupiona wynosi 14,11 kN. Powoduje ona wystąpienie naprężenia zginającego $\mathrm{w}$ belce na poziomie $14,11 \mathrm{kN} / 67,1 \mathrm{~cm}^{3}=210 \mathrm{MPa}$, czyli $89 \%$ granicy plastyczności. Zakres siły od wartości $14,11 \mathrm{kN}$ do zera został podzielony na 10 równych części, tak aby zbadać również naprężenia w spoinie dla niższych wartości obciążenia.

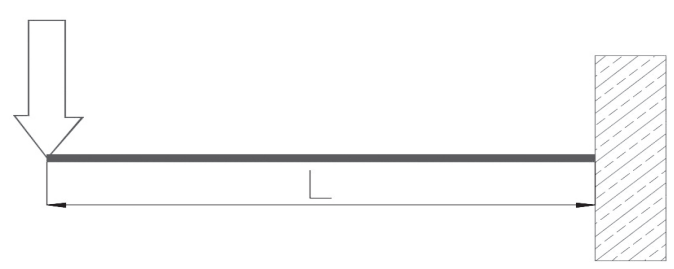

Rys. 1. Schemat obciążenia belki

Fig. 1. Beam load diagram

Mgr inż. Jerzy Nawrocki - Bilfinger Tebodin Poland Sp. z o.o.; dr hab. inż. Jacek Słania, prof. PCz - Politechnika Częstochowska. Autor korespondencyjny/Corresponding author: jureknawrocki@gmail.com 


\section{Wymiary złączy spawanych}

Poniżej pokazano szkic spoin pachwinowych i czołowych. Pierwsza to spoina pachwinowa o grubości a $=5 \mathrm{~mm}$ $(0,7 \times 6,3=4,4 \mathrm{~mm})$, która jest zaprojektowana z niewielkim wtopieniem. Druga, czyli spoina czołowa z pełnym przetopem. Markery, czyli punkty rejestracji naprężenia lokalnego zaznaczono na rysunku 2. Dla spoiny pachwinowej jest on na ok. 1/5 wysokości przekroju krytycznego. Wartość ta wynika z jednej strony ze spodziewanej koncentracji naprężeń w tym rejonie, a z drugiej, z uwagi na spodziewaną osobliwość naprężenia, z konieczności zastosowania zasady de Saint-Venanta. Osobliwość naprężenia jest to miejsce, w którym wraz ze wzrostem gęstości siatki silnie nieliniowo wzrasta naprężenie, w ten sposób, że dla teoretycznego rozmiaru elementu skończonego równego zero naprężenie w punkcie jest nieskończone [5]. Dla spoiny czołowej rejestracja naprężenia lokalnego znajduje się w połowie wysokości przekroju krytycznego.

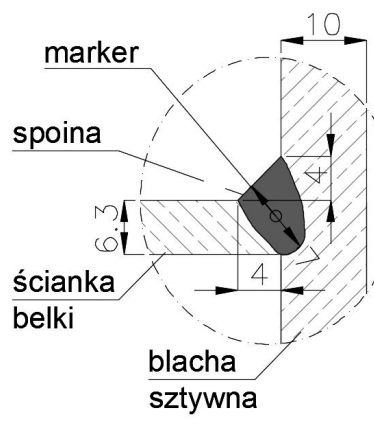

Rys. 2. Wymiary spoin

Fig. 2. Dimensions of the welds

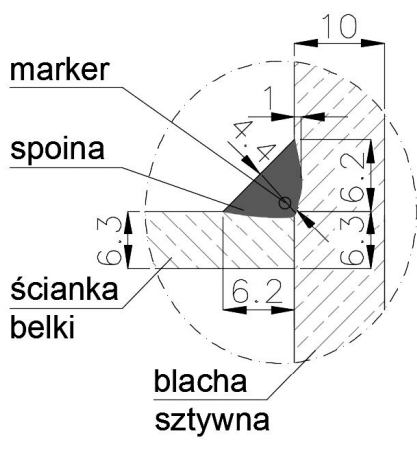

sztywna

\section{Dyskretyzacja}

Zastosowano podział na tetragonalne elementy skończone z uwzględnieniem zasady zagęszczenia siatki w miejscach o szczególnym znaczeniu, które na rysunku 3 zaznaczono czerwoną obwódką. Jest to fragment górnej krawędzi belki, gdzie spodziewane są największe naprężenia. Zachowano kształt wypukły lica spoiny, jako najbliższy rzeczywistości.

$\mathrm{Na}$ rysunku 4 pokazano zasadę modelowania wtopienia zgodnie z założeniami podanymi na rysunku 2, co ma zasadnicze znaczenie dla poprawności symulacji. Zdecydowano się na lokalne zagęszczenie siatki spoiny, belki i blachy do wartości 0,3 mm w części wskazanej na rysunku 5.

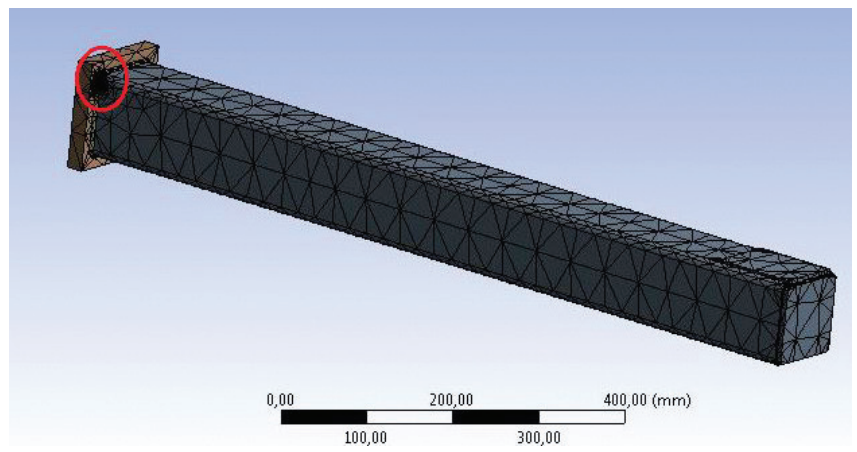

Rys. 3. Podział belki na elementy skończone

Fig. 3. Beam division into finite elements

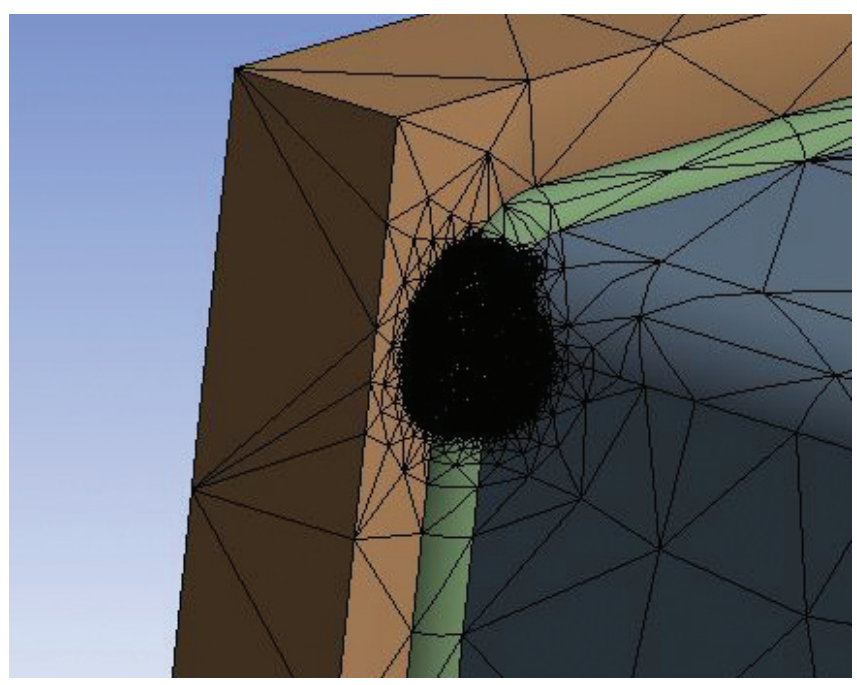

Rys. 5. Obszar spoiny z zagęszczoną siatką

Fig. 5. The area of the weld with compacted mesh

Na rysunku 6 pokazano jak różnica w zagęszczeniu siatki wpływa na późniejszy kształt izolinii naprężenia. Po prawej stronie na przekroju podłużnym w widoku z góry, na czerwono zakreślono obszar o siatce zagęszczonej zgodnie z rysunkiem 5. Wyraźnie widać, że kształty izolinii naprężenia są łagodne i bez kątów ostrych, w przeciwieństwie do lewej strony, gdzie siatka nie jest już tak zagęszczona.

Kolejnym elementem decydującym o jakości symulacji są zagadnienia kontaktu. W spoinie pachwinowej polega to na takim założeniu warunków brzegowych, aby styk płaszczyzny bocznej belki i blachy nie przenosił ani sił, ani momentów. Całość naprężeń, tak jak to jest w rzeczywistości, przechodzi tylko przez spoinę pachwinową. a)

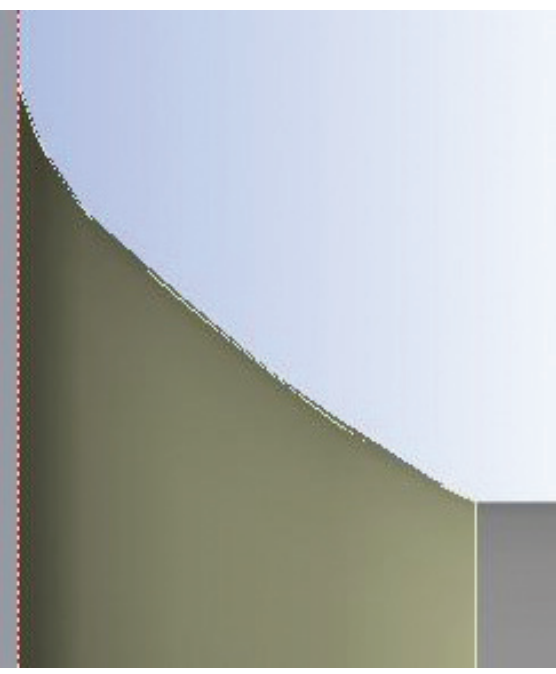

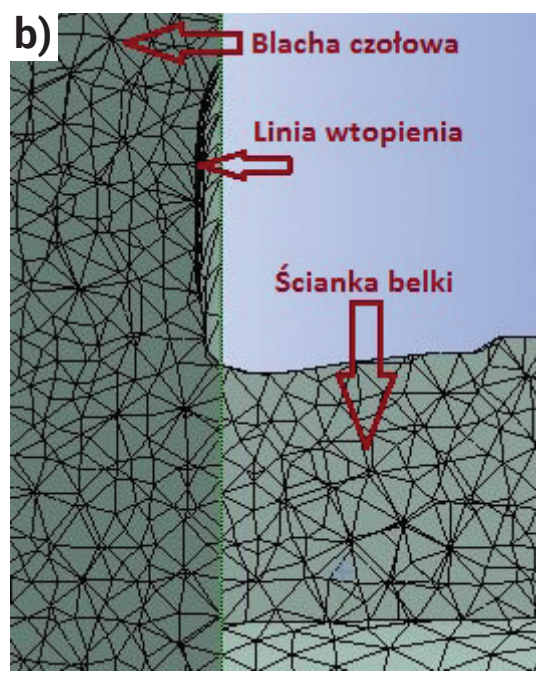

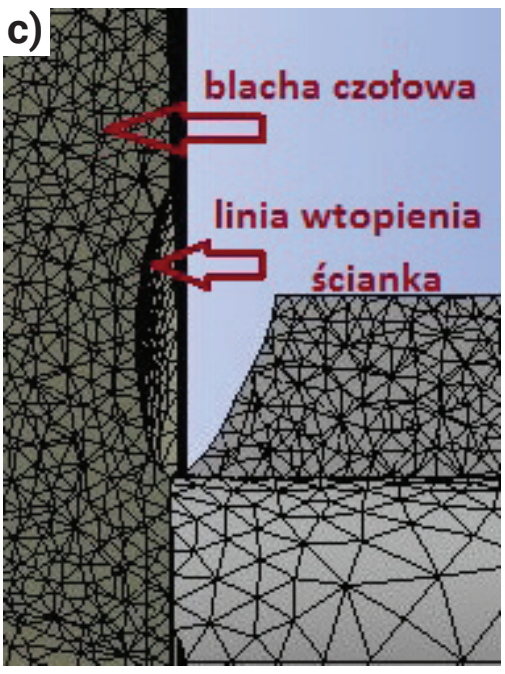

Rys. 4. Modelowanie wtopienia spoin: a)..., b) spoina pachwinowa, c) spoina czołowa

Fig. 4. Modeling of welds melting: a)..., b) fillet weld, c) butt weld 

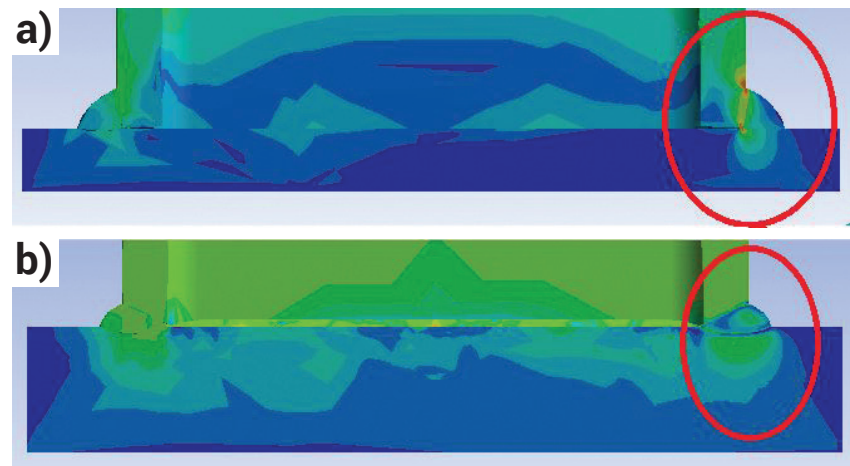

Rys. 6. Różnica kształtów izolinii naprężenia: a) spoina pachwinowa, b) spoina czołowa

Fig. 6. Differences in the shape of the isobars: a) fillet weld, b) butt weld

\section{Schemat obciążenia}

Dla obu wariantów spoin zastosowano dziesięć takich samych kombinacji obciążeń, w których z krokiem co 10\% zwiększano wartość siły skupionej (tabl. l).

Tablica I. Naprężenia zginające $w$ belce

Table I. Bending stresses in the beam

\begin{tabular}{|c|c|c|c|}
\hline $\begin{array}{c}\mathrm{Nr} \\
\text { symulacji }\end{array}$ & WWP [\%] & $F[N]$ & $\mathbf{k}_{\mathrm{g}}$ [MPa] \\
\hline 1 & 8,9 & 1411 & 21 \\
\hline 2 & 18 & 2822 & 42 \\
\hline 3 & 27 & 4233 & 63 \\
\hline 4 & 36 & 5644 & 84 \\
\hline 5 & 45 & 7055 & 105 \\
\hline 6 & 54 & 8466 & 126 \\
\hline 7 & 63 & 9877 & 147 \\
\hline 8 & 72 & 11288 & 168 \\
\hline 9 & 81 & 12699 & 189 \\
\hline 10 & 89 & 14110 & 210 \\
\hline
\end{tabular}

\section{Prezentacja wyników MES}

W celu przejrzystej prezentacji wyników symulacji zdecydowano się na przekrój poprzeczny spoiny. Na rysunku 7 pokazano wartości izolinii naprężenia zredukowanego Hubera-Misesa wraz z markerami wartości w punktach o szczególnym znaczeniu. Jak już wspomniano, symulacja spoiny pachwinowej została tak zdefiniowana, że pomiędzy ścianką belki a pionową blachą nie ma kontaktu przez węzły siatki. Innymi słowy, przez ten obszar nie są przekazywane ani siły, ani momenty węzłowe. W związku z tym na rysunku $7 a$ jest widoczna, zaznaczona białą elipsą, niewielka szczelina, która jest wynikiem rozciągania włókien górnych belki i ściskania dolnych. Drugim istotnym miejscem dotyczącym obu typów spoin jest obszar typowej osobliwości zaznaczonego czarną elipsą, które zaburza pole naprężenia w takim stopniu, że stosując zasadę de Saint-Venanta obszar ten wyłączono z analizy.

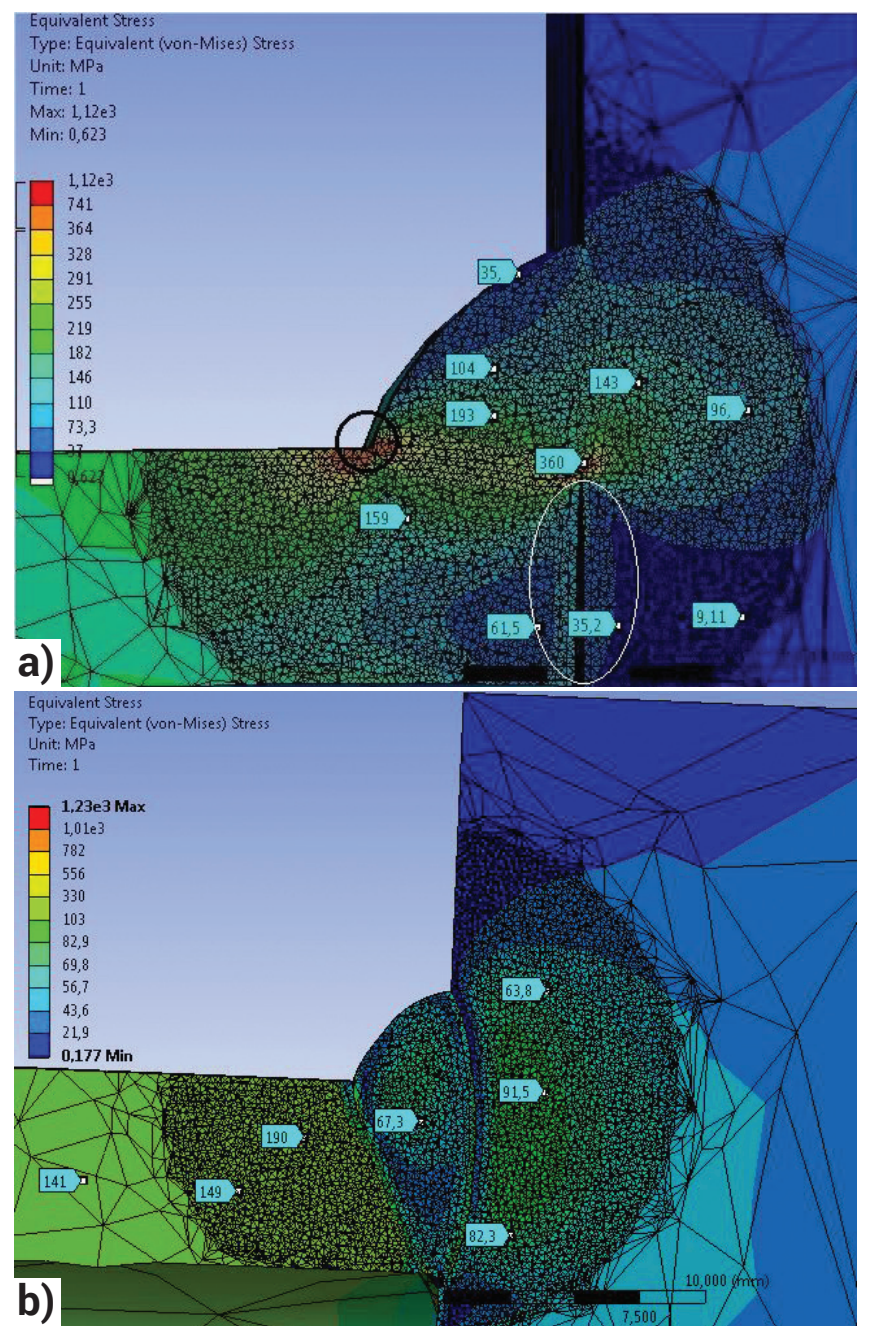

Rys. 7. Wartości naprężenia zredukowanego w przekroju spoin dla symulacji nr 10: a) spoina pachwinowa, b) spoina czołowa

Fig. 7. Huber-Mises valuse for simulation No 10: a) fillet weld, b) butt weld

Tablica II w przejrzysty i skrócony sposób podsumowuje wyniki wykonanej symulacji, w której naprężenie lokalne jest mierzone $w$ miejscu położenia markera zgodnie $z$ rysunkiem 2. Wewnątrz spoiny pachwinowej dochodzi do zjawiska lokalnego przekroczenia naprężenia zredukowanego powyżej wyliczonego, dopuszczalnego naprężenie przy zginaniu, a nawet powyżej granicy plastyczności materiału rodzimego.

Tablica II. Maksymalne naprężenia lokalne w spoinie pachwinowej wg metody MES

Table II. Maximum local stresses in the fillet weld according to the FEM method

\begin{tabular}{|c|c|c|c|}
\hline Nr symulacji & $\mathbf{k}_{\mathbf{g}}$ [MPa] & $\boldsymbol{\sigma}_{\text {MESP }}[\mathrm{MPa}]$ & Procent $\mathbf{R}_{\mathbf{p} 0,2}[\%]$ \\
\hline 1 & 21 & 12 & NIE \\
\hline 2 & 42 & 18 & NIE \\
\hline 3 & 63 & 28 & NIE \\
\hline 4 & 84 & 38 & NIE \\
\hline 5 & 105 & 48 & NIE \\
\hline 6 & 126 & 58 & NIE \\
\hline 7 & 147 & 82 & NIE \\
\hline 8 & 168 & 150 & NIE \\
\hline 9 & 189 & 241 & TAK / $102 \%$ \\
\hline 10 & 210 & 360 & TAK / $154 \%$ \\
\hline
\end{tabular}

$\sigma_{\text {MESP }}$ - lokalne, maksymalne naprężenie zredukowane wewnątrz spoiny pachwinowej wg metody MES 
Tablica III. Maksymalne naprężenia lokalne w spoinie czołowej wg metody MES

Table III. Maximum local stresses in the butt weld according to the FEM method

\begin{tabular}{|c|c|c|c|}
\hline Nr symulacji & $\mathbf{k}_{\mathbf{g}}$ [MPa] & $\sigma_{\text {MESC }}[\mathrm{MPa}]$ & Procent $\mathbf{R}_{\mathrm{p} 0,2}[\%]$ \\
\hline 1 & 21 & 11 & NIE \\
\hline 2 & 42 & 22 & NIE \\
\hline 3 & 63 & 33 & NIE \\
\hline 4 & 84 & 45 & NIE \\
\hline 5 & 105 & 57 & NIE \\
\hline 6 & 126 & 68 & NIE \\
\hline 7 & 147 & 83 & NIE \\
\hline 8 & 168 & 94 & NIE \\
\hline 9 & 189 & 106 & NIE \\
\hline 10 & 210 & 118 & NIE \\
\hline
\end{tabular}

Dla spoiny czołowej wyżej opisane zjawisko w ogóle nie zachodzi. Przy całkowitym przetopieniu materiału rodzimego ścianki belki, na całej jej grubości powoduje, że dystrybucja naprężeń zachodzi w całej objętości spoiny. Efektem tego jest to, że izolinie naprężenia mają charakterystyczny lagodny kształt.

\section{Weryfikacja modelu MES}

W celu weryfikacji założeń modelu obliczeniowego wykonano obliczenia analityczne ugięcia się belki i porównano je z wynikami symulacji. Ugięcie belki pod działaniem zginającej siły skupionej jest opisywane znanym wzorem [6]:

$$
f_{B}=\frac{\left(P \cdot a^{3}\right)}{(3 \cdot E \cdot J)}
$$

gdzie:

$\mathrm{f}_{\mathrm{B}}$ - strzałka ugięcia,

a - ramię działania siły równe długości belki $1 \mathrm{~m}$,

$P$ - siła skupiona $14110 \mathrm{~N}$,

$\mathrm{E}$ - moduł Younga $210 \mathrm{GPa}$

$\mathrm{J}$ - moment bezwładności względem osi obojętnej $336 \mathrm{~cm}^{4}$.

Dla rozpatrywanego przypadku obliczona wartość strzałki ugięcia wynosi $6,67 \mathrm{~mm}$. Model użyty w symulacji wykazał, mieszczącą się w granicy błędu, wartość o 6,4\% wyższą czyli 7,13 mm, co pokazano na rysunku 8.

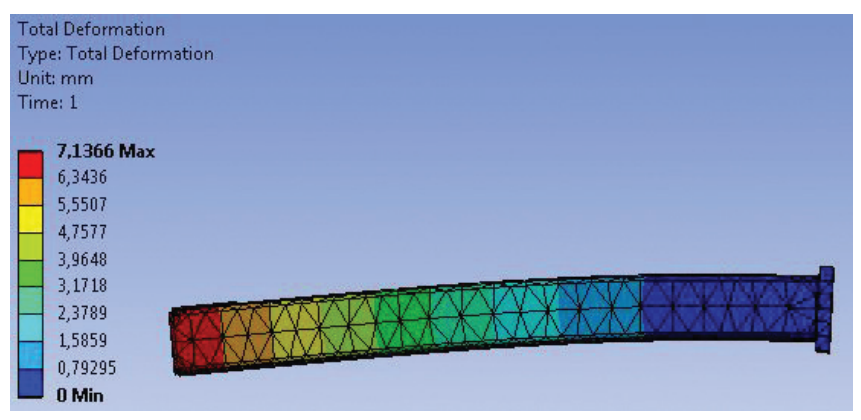

Rys. 8. Wartość ugięcia belki z symulacji

Fig. 8. The beam deflection value from the simulation

\section{Analityczne oszacowanie koncentracji naprężeń w licu spoiny pachwinowej}

Miejsce zaznaczone na rysunku 7a białą obwódką jest typowym przykładem sposobu pękania typu I [6]. Z tego powodu podjęto próbę oszacowania wartości naprężenia w wierzchołku szczeliny traktując ją jak klasyczne pęknięcie oraz porównania jego z wynikami symulacji.

Stan naprężenia przed frontem pęknięcia jest opisany znanymi równaniami Williamsa-Irwina [7], które dla analizowanego przypadku można uprościć do wzorów:

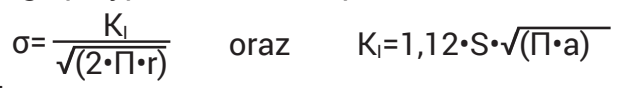

gdzie:

$\sigma$ - naprężenie przed frontem pęknięcia,

$\mathrm{K}_{\mathrm{l}}$ - współczynnik intensywności naprężeń $\mathrm{MPa} \cdot \sqrt{\mathrm{m}}$,

$r$ - promień przed frontem pęknięcia 0,2 mm,

a - długość szczelny $6 \mathrm{~mm}$,

$\mathrm{S}$ - naprężenie w przekroju pęknięcia brutto bez uwzględnienia szczeliny wynoszące 6,3/11,2•159 = 89,4 MPa (rys. 9).

Wyznaczona analitycznie wg podanych wzorów wartość naprężenia przed frontem pęknięcia wynosi $387 \mathrm{MPa}$.

$\mathrm{Na}$ rysunku 10 przedstawiono powiększenie obszaru spoiny pachwinowej zaznaczonego białą elipsą na rysunku $\mathrm{nr} 7 \mathrm{a}$, gdzie odczytana wartość naprężenia przed frontem szczeliny wynosi $391 \mathrm{MPa}$.

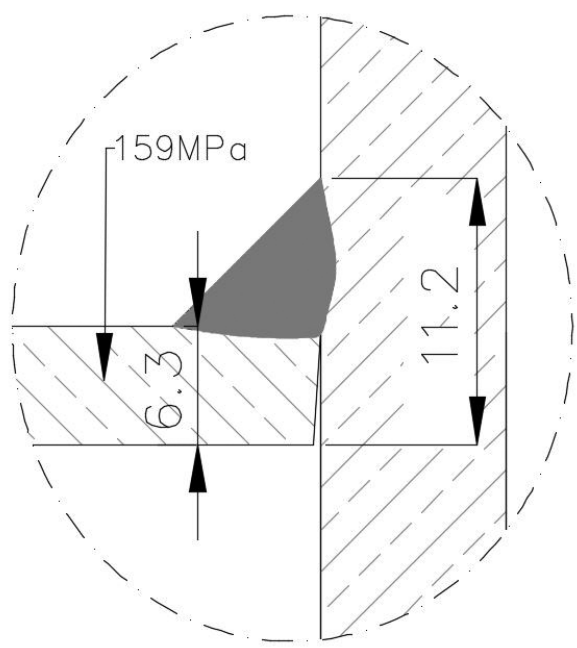

Rys. 9. Zasady szacowania naprężenia w przekroju

Fig. 9. Dimensions of the welds

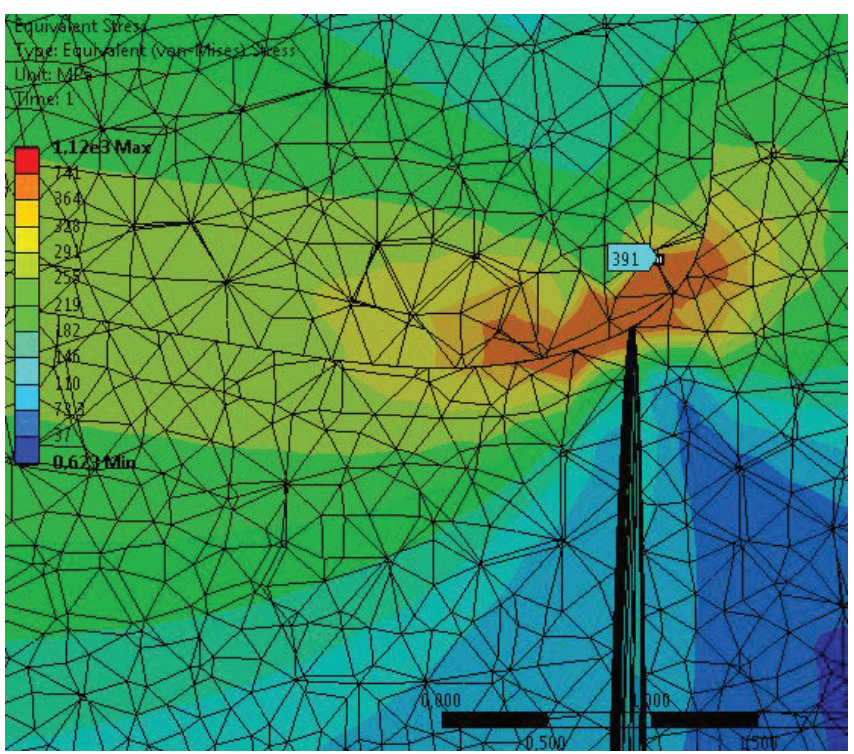

Rys. 10. Krytyczne miejsce spoiny pachwinowej

Fig. 10. The critical area of the filled weld 


\section{Prezentacja wyników metody kierunkowej}

W następnym etapie naprężenia zredukowane w spoinie pachwinowej policzono metodą kierunkową zgodnie z Eurokodem [3]. Dla najbardziej niekorzystnej kombinacji obciążeń reprezentowanej przez symulację nr 10 nośność obliczeniowa jest wystarczająca, ponieważ spełnione są dwa warunki, wyniki zaprezentowano w tablicy IV:

$$
\begin{aligned}
& \sigma_{\text {red }}=\sqrt{\sigma_{\perp}{ }^{2}+3\left(\mathrm{~T}_{\perp}{ }^{2}+\mathrm{T}_{\|}{ }^{2}\right.} \leq \frac{f_{\mathrm{u}}}{\mathrm{B}_{\mathrm{w}} \times \gamma_{\mathrm{M} 2}} \\
& \sigma_{\perp} \leq \frac{0,9 \times f_{\mathrm{u}}}{\gamma_{\mathrm{M} 2}}
\end{aligned}
$$

Tablica IV. Naprężenia zredukowane w spoinie pachwinowej wg metody kierunkowej

Table IV. Stresses reduced in the fillet weld according to the directional method

\begin{tabular}{|c|c|c|c|c|c|}
\hline Nr symulacji & 1 & 2 & 3 & 4 & 5 \\
\hline$\sigma_{\text {red }}[\mathrm{MPa}]$ & 28,6 & 57,1 & 85,7 & 114 & 143 \\
\hline Nr symulacji & 6 & 7 & 8 & 9 & 10 \\
\hline$\sigma_{\text {red }}[\mathrm{MPa}]$ & 171 & 200 & 228 & 257 & 286 \\
\hline
\end{tabular}

\section{Wnioski}

Podstawowym wnioskiem z wykonanej symulacji jest obserwacja specyficznego kształtu pola naprężeń w spoinie pachwinowej, które może generować koncentrację naprężeń. Dla wysokich wartości projektowanego współczynnika wykorzystania profilu, to jest od wartości ok. 70\% wzwyż. Spoina pachwinowa może generować naprężenia lokalne przekraczające granicę plastyczności. Z drugiej strony należy mieć na uwadze, że wykonana symulacja nie odzwierciedla przemian metalurgicznych struktury w spoinie i SWC. W procesie spawania stali C-Mn typu S 235 użytej w tej symulacji pojawiają się strefy szczególne. W tym wypadku jest to strefa podhartowania, gdzie struktura ferrytyczno-perlityczna przemienia się w martenzyt ze wzrostem twardości do ok. 350 HV [7]. Głównym celem wykonanej symulacji nie było jednak wyznaczenie bezpiecznych wartości naprężenia w złączu spawanym, ale pokazanie jedynie jego rozkładu.

Drugi wniosek dotyczy techniki modelowania spoin oraz wystąpienia osobliwości naprężenia. Analiza MES idealnie nadaje się do projektowania części maszyn z tego względu, że cała geometria jest ściśle określona i kontrolowana pod kątem unikania karbów naprężeń. Modelowanie lica spoiny pokazało, że próba odtworzenia jego naturalnych kształtów może generować osobliwość naprężenia znacznie utrudniając interpretację wyników.

Trzeci wniosek dotyczy krytycznego miejsca w spoinie pachwinowej przedstawionego na rysunku 10. W tym miejscu daje się zauważyć lokalne naprężenie o wartości ok. $400 \mathrm{MPa}$, co mniej więcej odpowiada wartości oszacowanej w oparciu o zależności mechaniki pękania. Należy jednak podkreślić, że wniosek ten jest traktowany jako wstępny i dotyczy tylko symulacji nr 10. Oszacowano, że do rozstrzygnięcia tego problemu konieczne jest lokalne zagęszczenie siatki do wartości nie większej niż 0,01 mm. Spowoduje to wzrost ilości węzłów i elementów skończonych do wartości kilkudziesięciu milionów. Tego typu zagadnienia są możliwe do rozwiązania w rozsądnym czasie wyłącznie na komputerach wieloprocesorowych.

Czwartą obserwacją jest kształt izolinii naprężenia dla spoiny czołowej. Charakteryzują się one łagodnym przejściem na linii: ścianka belki - spoina - blacha. Jest to wynikiem tego, że przy założonym w symulacji typie kontaktu, siły i momenty są przekazywane przez węzły elementów skończonych bez żadnych przeszkód. W przypadku spoiny pachwinowej nie ma trwałego kontaktu pomiędzy ścianką belki a blachą, zatem nie ma takiego typu kontaktu. Jest jedynie styk pomiędzy tymi elementami. To zjawisko właśnie jest podstawową przyczyną kształtów izolinii naprężenia pokazanych na rysunku 11.

Piąty wniosek dotyczy porównania wyników metody kierunkowej i MES. Metoda kierunkowa nie wykazuje przekroczeń naprężeń uznawanych przez PN-EN 1993-1-8:2006 za bezpieczne. Trudno jednak porównywać wyniki obu metod, ponieważ metoda kierunkowa uśrednia naprężenia dla całej wysokości przekroju krytycznego spoiny, podczas gdy metoda MES jest w stanie pokazać naprężania w niemalże każdym punkcie tego przekroju.

Szósty wniosek jest ogólnej natury. Jeżeli przyjmiemy, że wyniki symulacji są wiarygodne, to dla najbardziej odpowiedzialnych konstrukcji łączonych spoiną pachwinową warto rozważyć użycie dodatkowego współczynnika redukcyjnego.
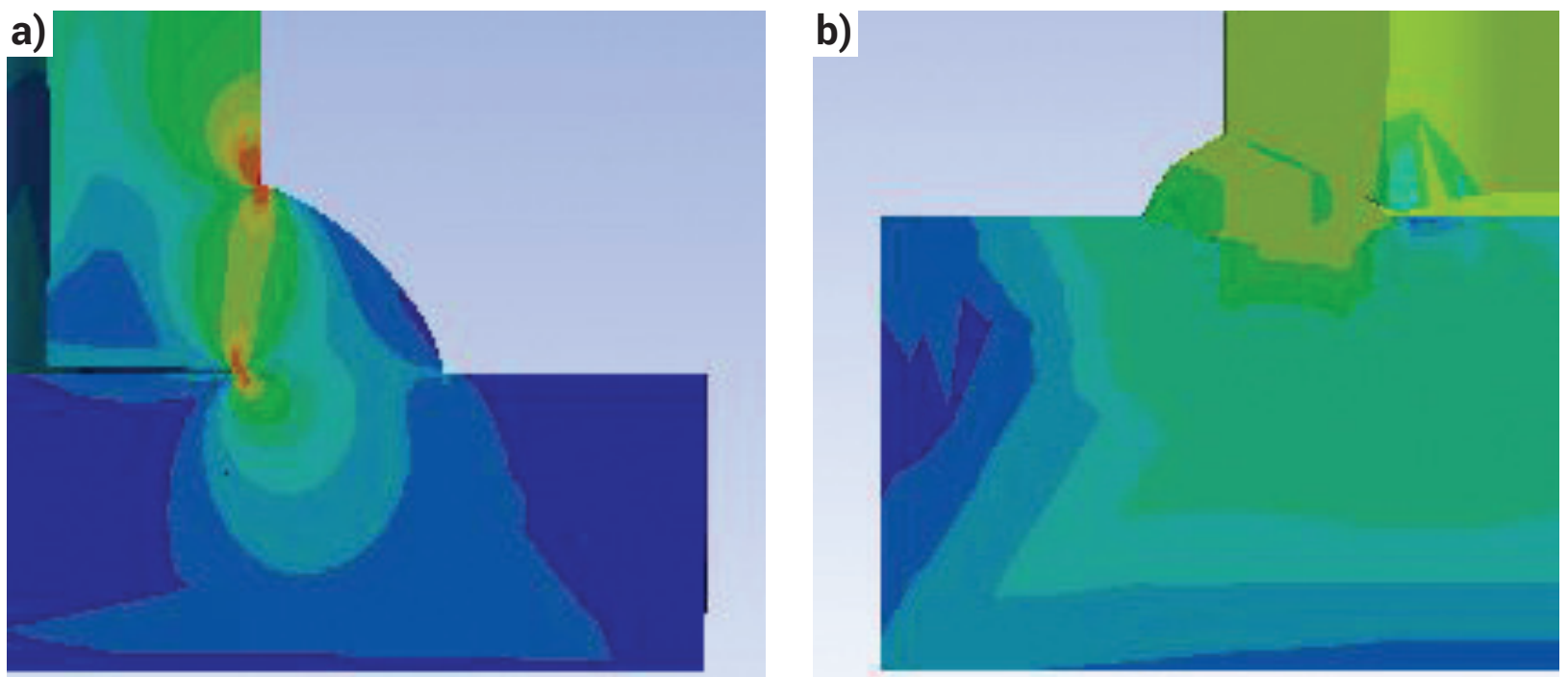

Rys. 11. Różnica kształtów izolinii naprężenia w obszarze złącza spawanego: a) spoina pachwinowa, b) spoina czołowa

Fig. 11. Differences in the shape of the isobars of the welded joint: a) fillet weld, b) butt weld 


\section{Literatura}

[1] Śledziewski E.: Konstrukcje Spawane. Projektowanie, WNT, Warszawa 1961.

[2] Ferenc K., Ferenc J.: Konstrukcje spawane. Połączenia. WNT, Warszawa 2003

[3] PN-EN 1993-1-8:2006 Eurokod 3: Projektowanie konstrukcji stalowych - Część 1-8: Projektowanie węzłów, 2006.

[4] PN-EN 10025-2:2007-Wyroby walcowane na gorąco ze stali konstrukcyjnych - Część 2: Warunki techniczne dostawy stali konstrukcyjnych niestopowych, 2007.

[5] Zienkiewcz O.C., Taylor R.L., Zhu J.Z.: The Finite Element Method. It's Basis \& Fundamentals, Butterworth-Heinemann, Oxford 2005.

[6] Brózda J.: Wprowadzenie do mechaniki pękania, Instytut Spawalnictwa, Gliwice 2008.

[7] Wyrzykowski J.W., Pleszakow E., Sieniawski J.: Odkształcenie i pękanie metali, WNT, Warszawa 1999.

[8] Praca zbiorowa pod red. Pilarczyka J.: Poradnik inżyniera. Spawalnictwo, WNT, Warszawa 2014.

[9] Roache J.P.: Fundamentals of Verification and Validation, 1998. 